\title{
Hypotension and Reduced Nitric Oxide-elicited Vasorelaxation in Transgenic Mice Overexpressing Endothelial Nitric Oxide Synthase
}

\author{
Yoshitaka Ohashi, ${ }^{*}$ Seinosuke Kawashima, ${ }^{*}$ Ken-ichi Hirata, ${ }^{*}$ Tomoya Yamashita, ${ }^{*}$ Tatsuro Ishida, ${ }^{*}$ Nobutaka Inoue, ${ }^{*}$ \\ Tsuyoshi Sakoda, ${ }^{*}$ Hiroki Kurihara, ${ }^{\ddagger}$ Yoshio Yazaki, ${ }^{\ddagger}$ and Mitsuhiro Yokoyama* \\ *The First Department of Internal Medicine, Kobe University School of Medicine, Kobe, Japan; and Department of Cardiovascular \\ Medicine, Graduate School of Medicine, University of Tokyo, Tokyo, Japan
}

\begin{abstract}
Nitric oxide (NO), constitutively produced by endothelial nitric oxide synthase (eNOS), plays a major role in the regulation of blood pressure and vascular tone. We generated transgenic mice overexpressing bovine eNOS in the vascular wall using murine preproendothelin-1 promoter. In transgenic lineages with three to eight transgene copies, bovine eNOS-specific mRNA, protein expression in the particulate fractions, and calcium-dependent NOS activity were confirmed by RNase protection assay, immunoblotting, and L-arginine/citrulline conversion. Immunohistochemical studies revealed that eNOS protein was predominantly localized in the endothelial cells of aorta, heart, and lung. Blood pressure was significantly lower in eNOS-overexpressing mice than in control littermates. In the transgenic aorta, basal NO release (estimated by $N^{\omega}$-nitro-L-arginine-induced facilitation of the contraction by prostaglandin $\mathrm{F}_{2 \alpha}$ ) and basal cGMP levels (measured by enzyme immunoassay) were significantly increased. In contrast, relaxations of transgenic aorta in response to acetylcholine and sodium nitroprusside were significantly attenuated, and the reduced vascular reactivity was associated with reduced response of cGMP elevation to these agents as compared with control aortas. Thus, our novel mouse model of chronic eNOS overexpression demonstrates that, in addition to the essential role of eNOS in blood pressure regulation, tonic NO release by eNOS in the endothelium induces the reduced vascular reactivity to NO-mediated vasodilators, providing several insights into the pathogenesis of nitrate tolerance. (J. Clin. Invest. 1998. 102:2061-2071.) Key words: transgenic animals $\bullet$ nitric oxide $\bullet$ endothelium $\bullet$ blood pressure $\bullet$ vascular reactivity
\end{abstract}

\section{Introduction}

Nitric oxide (NO), ${ }^{1}$ which is produced by endothelial cells, serves as an endothelium-derived relaxing factor which medi-

Address correspondence to Mitsuhiro Yokoyama, M.D., The First Department of Internal Medicine, Kobe University School of Medicine, 7-5-1 Kusunoki-cho, Chuo-ku, Kobe 650, Japan. Phone: 81-78341-7451, ext. 5501; FAX: 81-78-341-1390; E-mail: yokoyama@med. kobe-u.ac.jp

Received for publication 24 June 1998 and accepted in revised form 22 October 1998.

J. Clin. Invest.

(C) The American Society for Clinical Investigation, Inc. 0021-9738/98/12/2061/11 \$2.00

Volume 102, Number 12, December 1998, 2061-2071

http://www.jci.org ates vascular relaxation in response to vasoactive substances and shear stress (1). Several lines of evidence point to the key role of $\mathrm{NO}$ in the regulation of blood pressure and blood flow, and NO acts as an antithrombogenic and antiatherogenic molecule by inhibiting vascular smooth muscle proliferation, platelet aggregation, and leukocyte adhesion (2). Abnormalities of endothelial production or metabolism of NO occur in pathological conditions such as atherosclerosis, diabetes, and hypertension (3). NO is produced from L-arginine and oxygen by three nitric oxide synthase (NOS) isoforms: two constitutive forms, i.e., neuronal NOS (nNOS, NOS1) and endothelial NOS (eNOS, NOS3), and inducible NOS (iNOS, NOS2) (4). NO produced by these NOS isoforms, which are expressed in specific cell types, has been thought to exert distinct actions in various physiological functions and pathological processes. A wide variety of actions of $\mathrm{NO}$ has been elucidated in in vitro and in vivo experiments using NOS inhibitors and NO donors $(1,5)$. However, such pharmacological modulations of $\mathrm{NO}$ production affect multiple NOS isoforms, making it difficult to assess the specific roles of each isoform.

Recent advances in molecular biology and genetic engineering have enabled us to modulate the expression of a single NOS isoform and to identify the in vivo roles of the specific NOS isoform in complex physiological systems. Experiments involving hypertensive mice lacking the eNOS gene $(6,7)$ and eNOS gene transfer to normal or injured vessels $(8,9)$ have demonstrated that NO produced by eNOS plays a pivotal role in the regulation of blood pressure, vascular tone, and vascular homeostasis. In contrast to gene transfer for acute therapeutic benefits, the chronic actions of lifelong overexpression of eNOS in endothelial cells are still unknown. Thus, we generated transgenic mice overexpressing eNOS and determined their phenotypic changes.

\section{Methods}

Materials. $\quad N^{\omega}$-nitro-L-arginine methyl ester (L-NAME), $N^{\omega}$-nitro-L-arginine (L-NA), NADPH, flavin adenine dinucleotide, calmodulin, nitrate reductase (Aspergillus species), $\mathrm{PGF}_{2 \alpha}$, acetylcholine chloride (ACh), ATP $\gamma \mathrm{S}$, sodium nitroprusside (SNP), forskolin, and $N^{6}, 2^{\prime}$ $O$-dibutyryladenosine $3^{\prime}, 5^{\prime}$-cyclic monophosphate (dibutyryl cAMP) were purchased from Sigma Chemical Co. (St. Louis, MO). Nitroglycerin (NTG) was obtained from Nippon Kayaku (Tokyo, Japan). EGTA was purchased from Dojindo Laboratories (Kumamoto, Japan). A rabbit polyclonal anti-human eNOS Ab was obtained from

1. Abbreviations used in this paper: $\mathrm{ACh}$, acetylcholine chloride; EIA, enzyme immunoassay; eNOS, endothelial NOS; ET-1, endothelin-1; L-NA, $N^{\omega}$-nitro-L-arginine; L-NAME, $N^{\omega}$-nitro-L-arginine methyl ester; NO, nitric oxide; NOS, nitric oxide synthase; NTG, nitroglycerin; sGC, soluble guanylate cyclase; SNP, sodium nitroprusside. 
Transduction Laboratories (Lexington, KY). This $\mathrm{Ab}$ has been proven to cross-react with mouse and bovine eNOS (10) but not to recognize inducible NOS. All other reagents used were of the highest purity commercially available. All animal experiments were conducted according to the Guidelines for Animal Experimentation at Kobe University School of Medicine (approval number P950430).

Plasmid construction. To target eNOS gene expression to the vascular wall, we decided to use murine preproendothelin-1 (preproET-1) promoter (GenBank accession number U07982) as described (11). Bovine eNOS cDNA (GenBank accession number M99057, $4.1 \mathrm{~kb})(12)$ was excised from pBluescriptII SK(+) (Stratagene, La Jolla, CA) plasmids (a generous gift from D.G. Harrison, Emory University, Atlanta, GA) by NotI digestion at the EcoRI linker (EcoRI-NotI-SalI) ligated to both ends of the eNOS cDNA. Plasmids, designated as PEP8, comprised pCDM8 backbone (Invitrogen, San Diego, CA), the 9.2-kb murine preproET-1 5' flanking promoter, single NotI site, and SV40 intron polyA signal (13). Bovine eNOS cDNA was inserted into PEP8 at the NotI site downstream from the preproET-1 promoter. Orientation of the cDNA insert was confirmed by restriction enzyme digestion and the cloning junction was sequenced by the dideoxy termination method (Sequenase Version II sequencing kit; United States Biochemical, Cleveland, OH). Standard cloning methodologies were used for all DNA manipulations. The resultant plasmids, designated as PEP-NOS, were double $\mathrm{CsCl}$-purified and used for in vitro transfection and generation of eNOS transgenic mice.

Generation of transgenic mice. PEP-NOS $(16.4 \mathrm{~kb})$ was linearized by SpeI digestion, purified by $0.5 \%$ agarose gel electrophoresis, and electro-eluted from agarose using Gene Capsule (Geno Technology, St. Louis, MO). The eluted fragment was further purified and concentrated with an Elutip D column (Schleicher \& Schuell, Dassel, Germany) and finally precipitated in ethanol. Purified DNA (2 ng/ $\mathrm{ml}$ ) free of agarose was finally dissolved in $5 \mathrm{mM}$ Tris $/ \mathrm{Cl}(\mathrm{pH} 7.5)$ and $0.1 \mathrm{mM}$ EDTA before pronuclear microinjection. Fertilized eggs were prepared from superovulated BDF1 (B6D2F1; C57BL/6 $\times$ DBA/2 F1) mice (Charles River Japan, Osaka, Japan). Microinjected embryos were then transferred into the oviducts of pseudopregnant Institute for Cancer Research foster mothers (Clea Japan, Osaka, Japan) and allowed to develop to term. All procedures were performed using standard techniques (14) with microscopes and micromanipulators (Leica, Heerbrugg, Switzerland), a micropipette puller (Sutter Instrument, Novata, CA), and a microforge (Technical Products International, St. Louis, MO). The mice were maintained under controlled environmental conditions with respect to temperature $\left(20^{\circ} \mathrm{C}\right)$ and humidity $(64 \%)$ on a 12 -h light/dark cycle, and provided with standard chow and water ad libitum.

PCR and Southern blot analysis. Founder mice harboring the transgene were identified by PCR and subsequent Southern blot analysis of genomic DNA isolated from tail biopsies at 3-4 wk of age. Tail DNA was extracted by proteinase $\mathrm{K}(1.4 \mathrm{mg} / \mathrm{ml}$; Boehringer Mannheim, Mannheim, Germany) digestion and subsequent phenolization and purification using a Genomix DNA extraction kit (Talent, Trieste, Italy). PCR detection was performed using transgene-specific oligonucleotide primers, i.e., sense primer at the $3^{\prime}$ end of preproET-1 promoter (5'-GAAGTTAGCCGTGATTTCCTCTAGAGCCGGGTC) and antisense primer at the $5^{\prime}$ end of eNOS cDNA (5'-TTGATGAAGTCCCTGGCCTGGCTCAGCAG). In genomic Southern blot analysis for eNOS genotyping, tail DNA $(15 \mu \mathrm{g})$ digested with HindIII and SalI endonucleases was electrophoresed in $0.5 \%$ agarose, transferred to nitrocellulose filters (Schleicher \& Schuell) and hybridized at $42^{\circ} \mathrm{C}$ with a random-primed, ${ }^{32} \mathrm{P}$-labeled SacI-digested fragment $(1.1 \mathrm{~kb})$ of bovine eNOS cDNA, which contains calmodulin and flavin mononucleotide binding sites (12), or a whole transgene $(16.4 \mathrm{~kb})$. After washing, the hybridized filters were analyzed with a bio-imaging analyzer (Fujix BAS2000; Fuji Photo Film, Tokyo, Japan). Transgene copy number was calculated using known amounts of the transgene added to nontransgenic mouse genomic DNA as a control.
Preparation of total RNA and ribonuclease protection assay. Total RNA was extracted from pooled tissues by the acid guanidinium thiocyanate-phenol/chloroform method (15). To confirm specific expression of bovine eNOS mRNA, we used a ribonuclease (RNase) protection assay that distinguishes the transgene transcript from the endogenous mouse eNOS and other NOS isoform gene transcripts. The region, containing the $\mathrm{NH}_{2}$-terminal myristoylation site of bovine eNOS cDNA (from -15 to 225 ), amplified with forward primer NP-1 (5'-ATAGAATTCACCAGCACCTTTGGGAATGGCGAT) and reverse primer Cp-11 (5'-ATAGAATTCGGATTCACTGTCTGTGTTGCTGGACTCCTT) and the 124-bp ApaI-AluI fragment of rat GAPDH cDNA, was subcloned, linearized, and in vitro transcribed with SP6 and T7 RNA polymerase (Promega, Madison, WI), as described $(12,16)$. RNase protection assay was performed with a PRAII kit (Ambion, Austin, TX). In brief, an aliquot of total RNA $(10 \mu \mathrm{g})$ was hybridized with ${ }^{32} \mathrm{P}$-labeled riboprobes for $14-16 \mathrm{~h}$ at $50^{\circ} \mathrm{C}$ in $80 \%$ formamide hybridization buffer, followed by digestion with ribonuclease $\mathrm{A}$ and ribonuclease $\mathrm{T} 1$ at $37^{\circ} \mathrm{C}$ for $30 \mathrm{~min}$. After simultaneous precipitation of RNA and inactivation of ribonuclease, the protected fragments were separated in $8 \mathrm{M}$ urea $/ 5 \%$ acrylamide denaturing gel and the relative signal intensities were determined with the bio-image analyzer.

Immunoblotting of eNOS and Ca-dependent eNOS activity. Crude homogenates of pooled tissues in a homogenizing buffer of $50 \mathrm{mM}$ Tris-HCl, pH 7.4, 1 mM EGTA, 1 mM DTT, $1 \mu \mathrm{M}$ pepstatin A, $2 \mu \mathrm{M}$ leupeptin, and $1 \mu \mathrm{M}$ ( $p$-amidinophenyl) methanesulfonyl fluoride were ultracentrifuged at $100,000 \mathrm{~g}$ to collect cytosolic fractions. The pellets were solubilized in the homogenizing buffer containing $10 \%$ glycerol and $20 \mathrm{mM}$ 3-[(3-chol-amidopropyl)dimethylammonio]1-propanesulfonate and ultracentrifuged to extract particulate fractions. Protein concentrations were determined by the method of Bradford (Bio-Rad Laboratories, Hercules, CA) with BSA fraction $\mathrm{V}$ as a standard protein (17). Immunoblotting was performed as described (16). In brief, $150 \mu \mathrm{g}$ of protein samples, unless otherwise indicated, from either the cytosolic or particulate fraction was separated on a $7.5 \%$ SDS-polyacrylamide gel under reducing conditions, transferred to a polyvinylidene difluoride membrane (ATTO, Tokyo, Japan), and probed with a rabbit polyclonal (dilution, 1:500) or a murine monoclonal anti-bovine eNOS Ab (clone H32, IgG2a, 1:5,000) (18). Immunoreactive bands were visualized with horseradish peroxidase-conjugated anti-rabbit Ig $\mathrm{F}\left(\mathrm{ab}^{\prime}\right)_{2}$ fragment or anti-mouse $\mathrm{IgG}$ using an ECL detection kit (Amersham International plc, Buckinghamshire, UK) and quantified by densitometry. NOS enzymatic activity was determined by the conversion of L-arginine to L-citrulline with saturating concentrations of substrate and cofactors as described (19). Enzyme activity was expressed as citrulline production in femtomoles per milligram of protein per minute. To test the specificity of calcium-dependent NOS, parallel reactions were performed in a separate buffer omitting calcium and calmodulin or containing $1 \mathrm{mM}$ L-NAME, a competitive NOS inhibitor.

Immunohistochemistry. To determine the tissue distribution of bovine eNOS expression, immunohistochemical staining was performed by the labeled streptavidin biotin (LSAB) method using an LSAB kit (DAKOPATTS, Copenhagen, Denmark) as described (20). Frozen sections were fixed in acetone, blocked with $10 \%$ BSA, and incubated with 1:50 dilution of the primary rabbit polyclonal antieNOS Ab. We used the polyclonal Ab because murine mAb could not be applied to mouse tissues. The sections were then incubated with biotinylated gout anti-rabbit IgG and subsequently with horseradish peroxidase-labeled streptavidin. Endogenous peroxidase was quenched with $\mathrm{H}_{2} \mathrm{O}_{2}$ and the bound primary $\mathrm{Ab}$ was detected with the substrate, diaminobenzidine. Specificity of staining was assessed by substitution of nonimmune serum for primary $\mathrm{Ab}$.

Blood pressure and heart rate measurements. At 3 mo of age, mice were anesthetized with $0.08 \mathrm{mg} / \mathrm{g}$ body wt pentobarbital sodium (Abbott Laboratories, North Chicago, IL). The right femoral arteries were cannulated with a short length of SP-8 tubing connected to SP31 tubing (Natsume Manufactory, Tokyo, Japan). For continuous 
measurement of arterial pressure and heart rate under conscious and unrestrained conditions, the femoral catheter was connected to a saline-filled pressure transducer (Bioresearch Center, Nagoya, Japan) using a free-moving cannulation system (Tsumura, Tokyo, Japan) and the signals were amplified and continuously monitored (13). At least $4 \mathrm{~h}$ after recovery from anesthesia, physiological parameters (systolic, diastolic, and mean blood pressures and heart rate) were accumulated on a Macintosh computer with MacLab systems (Bioresearch Center) every $5 \mathrm{~s}$ for $2 \mathrm{~h}$. In another experiment to study the effects of chronic NOS inhibition on systemic blood pressure, L-NAME $(1 \mathrm{mg} / \mathrm{ml})$ was given in drinking water for $2 \mathrm{wk}$ to both control littermates and eNOS-overexpressing mice.

Basal release of $N O$ from the aorta and vascular reactivity to endothelium-dependent and-independent vasodilators. The aortas with intact endothelium from either control or eNOS transgenic mice were dissected and cleaned of adhering tissues. Isometric tension was recorded as described (21). In brief, 3-mm-wide transverse aortic rings were mounted under $1.5 \mathrm{~g}$ resting tension on stainless steel hooks attached to force transducers (Nihon Kohden, Tokyo, Japan) in 30-ml organ chambers containing Krebs' bicarbonate solution ( $\mathrm{pH}$ 7.4) of the following composition $(\mathrm{mM}): \mathrm{NaCl} 118, \mathrm{KCl} 4.0, \mathrm{CaCl}_{2}$ 1.5, $\mathrm{MgSO}_{4} 1.2, \mathrm{NaH}_{2} \mathrm{PO}_{4} 1.2, \mathrm{NaHCO}_{3} 25$, and glucose 5, and equilibrated at $37^{\circ} \mathrm{C}$ with a $95 \% \mathrm{O}_{2} / 5 \% \mathrm{CO}_{2}$ gas mixture. Isometric tension was displayed using an amplifier system (Nihon Kohden) and a pen recorder (Nippon Densi Kagaku, Kyoto, Japan). A test contraction was induced by $40 \mathrm{mM} \mathrm{KCl}$. To elucidate the tone-related basal release of NO, moderate vascular tone was induced by a low concentration $(500 \mathrm{nM})$ of $\mathrm{PGF}_{2 \alpha}$ and the rings were subsequently contracted by cumulative additions of L-NA $(1-100 \mu \mathrm{M})$. Basal release of NO was indirectly estimated by L-NA-induced endothelium-dependent facilitation of the contraction elicited by $\operatorname{PGF}_{2 \alpha}(22,23)$. Next, to assess the vascular reactivity to endothelium-dependent and -independent vasodilators, aortic rings were submaximally precontracted with 1-3 $\mu \mathrm{M} \mathrm{PGF}$ P $_{2 \alpha}$ to develop $\sim 1.0 \mathrm{~g}$ tension. After the contraction reached a plateau, vasodilatory agents (ACh, ATP $\gamma$ S, SNP, NTG, forskolin, and dibutyryl cAMP) were added in a cumulative manner. Almost all experiments were performed on paired rings from transgenic mice and control littermates. Relaxations were expressed as the percentage of $\mathrm{PGF}_{2 \alpha}$-induced precontraction and a dose-response curve was obtained for each agent. To address the specificity and reversibility of NO-mediated changes in vascular reactivity, we measured the isometric tension of aortas from chronic L-NAME-treated mice in the presence of L-NAME $(100 \mu \mathrm{M})$.

Measurement of cGMP levels in the aorta and plasma nitrite and nitrate levels. Immediately after killing, aortas from either control or transgenic mice were homogenized in $6 \%$ TCA and centrifuged at $2,000 \mathrm{~g}$. TCA in the supernatant fraction was extracted with diethyl ether and the samples were then lyophilized. In some experiments, longitudinally opened thoracic aortas were preincubated for $60 \mathrm{~min}$ in Krebs' solution equilibrated at $37^{\circ} \mathrm{C}$ with a $95 \% \mathrm{O}_{2} / 5 \% \mathrm{CO}_{2}$ gas mixture and stimulated with ACh and SNP for $1 \mathrm{~min}$, and the increases in cGMP levels in response to vasodilators were determined. cGMP was measured using an enzyme immunoassay (EIA) kit (Amersham) as described (24). Samples were resuspended, acetylated with triethylamine/acetic anhydride, and subjected to EIA. cGMP levels were expressed as picomoles per milligram of TCA-precipitable protein solubilized with $1 \mathrm{~N} \mathrm{NaOH}$. At the time of killing, heart, lung, and kidney weights (wet weight) were measured for each animal and blood samples were collected. Nitrite and nitrate levels in heparinized plasma were measured as nitrite by using the Griess reaction after enzymatic conversion by nitrate reductase $(0.25 \mathrm{U} / \mathrm{ml})$ as described (25).

Blood biochemistry and analyses of neurohumoral regulatory factors. Blood urea nitrogen and plasma electrolyte concentrations were determined with a multiparameter autoanalyzer. To assess alterations of major neurohumoral factors regulating blood pressure, plasma renin activity was determined by radioimmunoassay of generated angiotensin I. Plasma epinephrine and norepinephrine levels were mea- sured by HPLC. Plasma ET-1 was extracted with a Seppak C-18 column (Waters, Milford, MA) and measured using a sandwich EIA kit (Wako Pure Chemicals, Osaka, Japan).

Statistics. Student's $t$ test for unpaired observations was used to determine the significance of differences between transgenic mice and control littermates. Statistical analysis for multiple comparisons was performed using one-way ANOVA with Bonferroni correction. All values are given as means $\pm \mathrm{SE}$, and statistical significance was set at $P<0.05$.

\section{Results}

In vitro transfection and generation of eNOS transgenic mice. HeLa cells (American Type Culture Collection, Rockville,

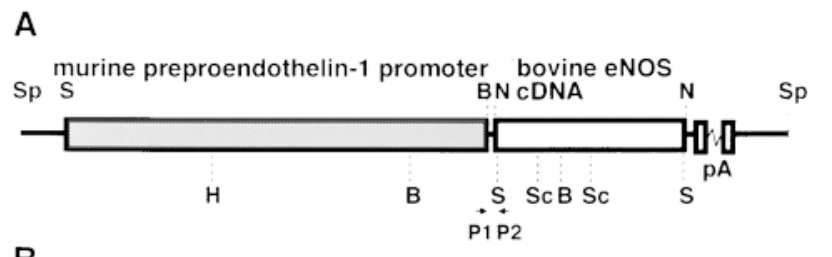

B
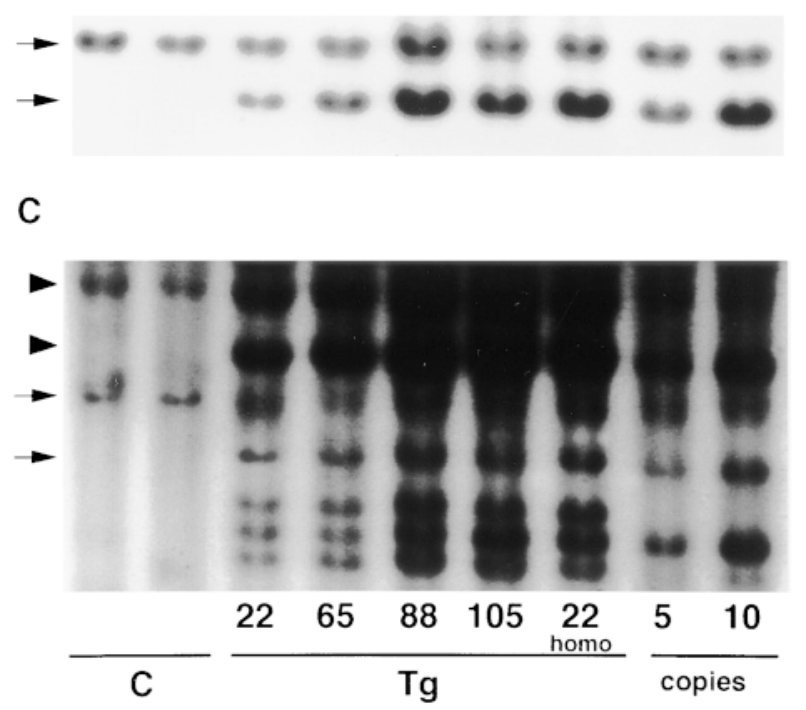

Figure 1. (A) Schematic map of the murine preproET-1 promoter/ bovine eNOS cDNA fusion gene used to generate eNOS transgenic mice. PreproET-1 promoter $(9.2 \mathrm{~kb})$ is depicted as a shaded bar and eNOS cDNA ( $4.1 \mathrm{~kb})$ as an open bar. pA represents SV40 intron/ polyA signal. P1 and P2 indicate oligonucleotide primers used to screen genomic DNA for the presence of the transgene. $S p$, SpeI; $S$, SalI; $H$, HindIII; $B$, BamHI; $N$, NotI; $S c$, SacI. $(B$ and $C$ ) Southern blot analysis for transgene integration. HindIII and SalI-digested tail DNA $(15 \mu \mathrm{g})$ was hybridized with SacI fragment of eNOS cDNA probe $(B)$ or whole transgene probe $(16.4 \mathrm{~kb})(C)$. The first and second lanes represent DNA isolated from transgene negative littermates $(C)$. The numbers of independent transgenic founders $(T g)$ are shown at the bottom of the third to sixth lanes. The seventh lane represents transgene homozygote (line 22). The eighth and ninth lanes are nontransgenic genomic DNA containing standard amounts of the transgene equivalent to 5 and 10 copies, respectively. Arrows indicate expected hybridizing bands (5 and $4.1 \mathrm{~kb}$ ) corresponding to endogenous mouse eNOS gene detected in both $\mathrm{C}$ and $\mathrm{Tg}$ and transgenederived bovine eNOS cDNA in both $\mathrm{Tg}$ and standards, respectively. Arrowheads indicate endogenous preproET-1 promoter $(8.0 \mathrm{~kb})$ and preproET-1 promoter in the transgene $(6.0 \mathrm{~kb})$. 
MD), which endogenously express ET-1 and have high transfection efficacy, were transfected by using lipofectamine reagent (GIBCO BRL, Gaithersburg, MD) with the plasmids PEP-NOS. PEP-NOS-transfected cells exhibited a marked increase in calcium-dependent NOS activity, as compared with those transfected with control plasmids containing bovine eNOS cDNA in reverse orientation (110.8 \pm 14.2 compared with $23.7 \pm 19.1 \mathrm{fmol} / \mathrm{mg}$ protein $/ \mathrm{min}$ in three independent experiments, data not shown), indicating that PEP-NOS expressed an enzymatically active eNOS protein under the control of the preproET-1 promoter. SpeI-linearized PEP-NOS was used as a transgene to generate mice overexpressing bovine eNOS (Fig. $1 A$ ). Four potential founder $\left(\mathrm{F}_{0}\right)$ mice were independently propagated to obtain offspring. Tail DNA from the transgenic founders (Nos. 22, 65, 88, 105) carrying multiple copies of transgenes was subjected to Southern blot analysis to detect tandem copies of the transgenes. As shown in Fig. $1 B$, genomic DNA encoding endogenous mouse eNOS allele in tail DNA from nontransgenic control littermates yielded a band of $\sim 5 \mathrm{~kb}$ excised by HindIII and SalI, when probed with the ${ }^{32}$ P-labeled SacI fragment of eNOS cDNA (6). In transgenic mice, besides the $\sim 5$-kb fragment of endogenous eNOS gene, $4.1 \mathrm{~kb}$ of bovine eNOS cDNA excised from transgene by SalI was specifically hybridized with the probe. Transgene copy number calculated by densitometric analysis was three to eight. Southern blot analysis using whole transgene probe showed that, in addition to endogenous and transgene-derived eNOS signals ( $\sim 5$ and $4.1 \mathrm{~kb}$, respectively), the 8-kb fragments detected in both transgenic and control DNA represented endogenous preproET-1 promoter excised by HindIII (13) and the 6-kb fragment of preproET-1 promoter excised from the transgene by HindIII and SalI was detected only in tail DNA from transgenic mice (Fig. $1 C$ ). Transgenic mice did not differ from control littermates in general appearance. They normally developed and were fertile, and transgenic offspring were obtained in Mendelian fashion. Since transgenic mice were prepared on a mixed genetic background, founders were subsequently backcrossed for at least three generations with the wild-type C57BL/6J strain of mice (Clea Japan) to ensure a genetically homogeneous background for the use in the studies described below. Offspring were weaned at $3 \mathrm{wk}$ of age and screened by PCR of tail DNA, for which oligonucleotide primers were selected so that the predicted amplification product was a distinctive fragment $(\sim 750 \mathrm{bp})$ created by the juxtaposition of the preproET-1 promoter and the bovine eNOS cDNA (Fig. $1 A$ ). In established colonies (lines 22, 65, 88, and 105), mice that were heterozygous at the transgene locus were used in all analyses and nontransgenic littermates served as controls.

Expression of bovine eNOS $m R N A$ and functional protein. RNase protection assay to detect bovine eNOS-specific mRNA revealed the transgene expression in the heart, lung, aorta, and uterus, and albeit to a lesser extent in the brain, liver, kidney, and intestine of four transgenic lineages examined (lines 22, 65, 88, and 105), whereas no transgene expression was detected in control littermates. Fig. $2 A$ shows representative findings for line 22 and the similar pattern of mRNA expression was observed in other transgenic lineages. In the particulate fractions of heart, lung, and aorta of transgenic mice, increased expression of eNOS protein $(135 \mathrm{kD})$ over endogenous mouse eNOS levels of control littermates was detected by immunoblotting with polyclonal Ab (Fig. 2 B). Immunoblotting with the murine monoclonal anti-bovine eNOS Ab confirmed the transgene expression in the particulate fractions of these organs since this $\mathrm{mAb}$ did not cross-react with mouse eNOS (Fig. 2 C). The calcium-dependent NOS activity was markedly increased in the particulate fraction of aorta from transgenic mice (11.0 \pm 6.6 vs. $86.2 \pm 10.0$ fmol citrulline/ $\mathrm{mg} / \mathrm{min}, P<0.05$, for three independent determinations). In the immunoblotting of the cytosol fraction with the polyclonal $\mathrm{Ab}$, no immunoreactive band was detected. There was no sig-

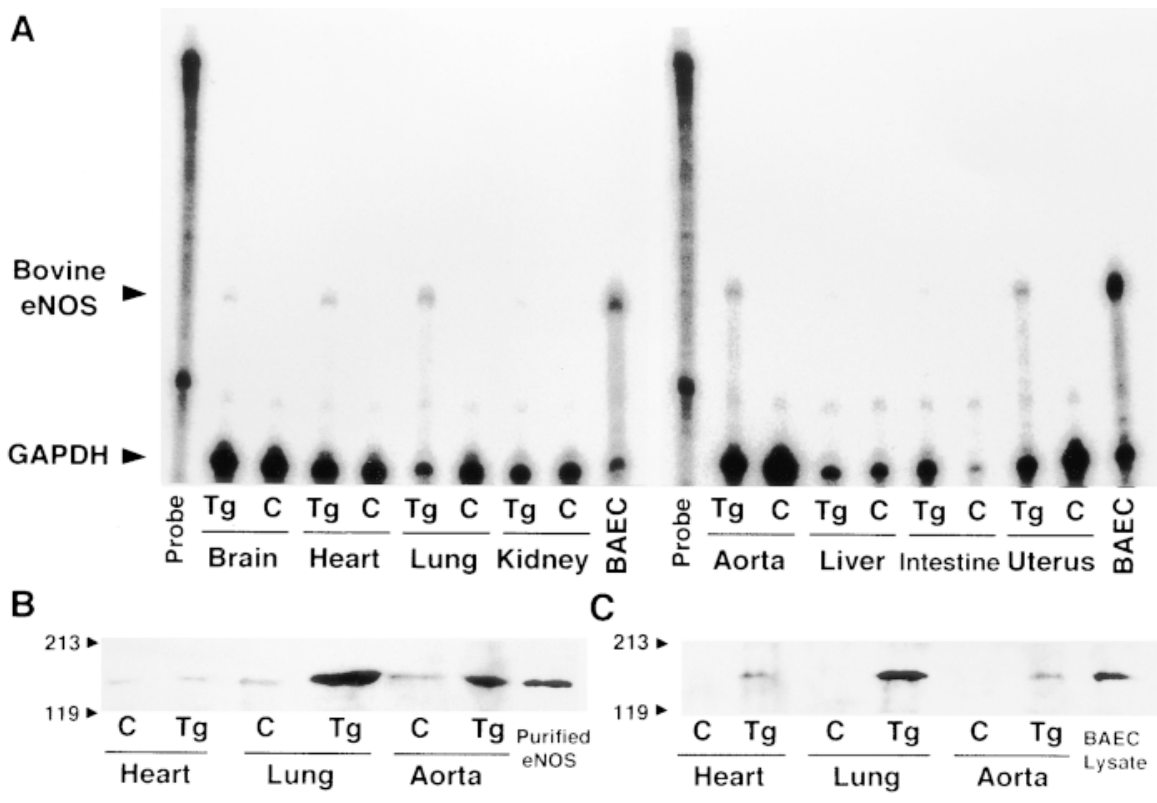

Figure 2. (A) Representative ribonuclease protection assay for bovine eNOS mRNA. $10 \mu \mathrm{g}$ of total RNA from designated organs of nontransgenic control mice $(C)$ and transgenic mice $(T g$, line 22$)$ was analyzed as described in Methods. The top arrowhead indicates the protected band corresponding to bovine eNOS-specific mRNA. Probe means free probe lane. Total RNA $(10 \mu \mathrm{g})$ extracted from cultured bovine aortic endothelial cells $(B A E C)$ served as a positive control. Glyceraldehyde-3-phosphate dehydrogenase (GAPDH) mRNA was used as a control for RNA integrity and loading. ( $B$ and $C$ ) Immunoblotting for eNOS protein, demonstrating increases in eNOS protein expression. The particulate fractions $(150 \mu \mathrm{g} / \mathrm{lane}$, except for heart in $C, 500 \mu \mathrm{g} / \mathrm{lane})$ were electrophoresed, transferred, and probed with a polyclonal anti-eNOS $\mathrm{Ab}$, shown in $B$, or with an anti-bovine eNOS mAb, in $C$. Purified NOS indicates bovine eNOS purified from BAEC (20 ng/lane), which was used as a positive control as well as BAEC lysate. Size markers in kilodaltons are shown to the left of the blot. 

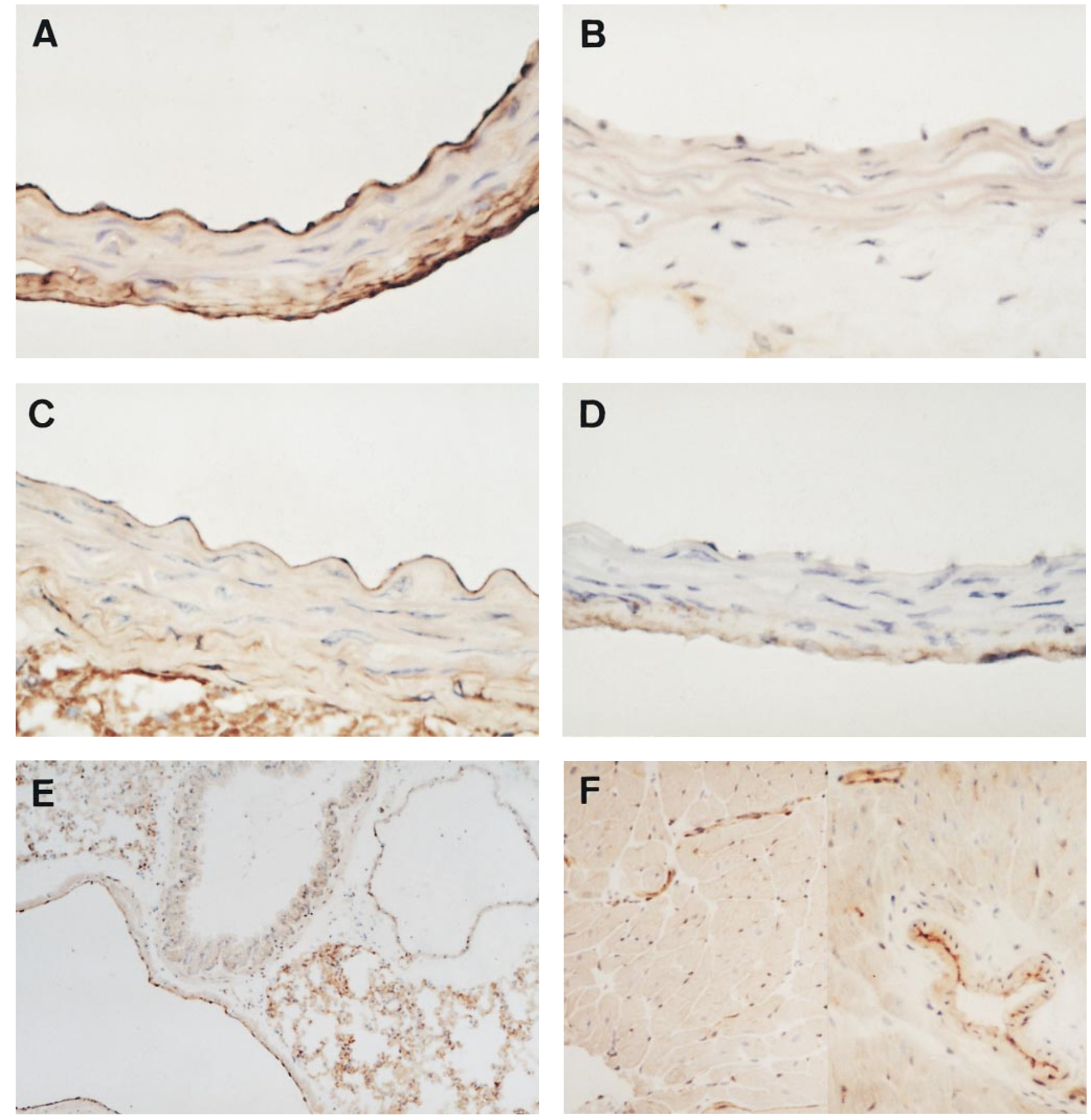

Figure 3. Immunohistochemical staining for eNOS in the aorta $(A-D)$, lung $(E)$, and heart $(F)$. Frozen sections of thoracic aorta from transgenic mice $(A)$ and control littermates $(C)$ were immunohistochemically stained using a rabbit polyclonal anti-eNOS Ab. Immunoreactive product is predominantly observed in the endothelial cell lining and the immunoreactivity is obviously stronger in transgenic aorta $(A)$ than in control aorta $(C)$. In $B$ and $D$, sections of transgenic and control aorta were stained with nonimmune serum to assure the specificity of reaction. In the lung $(E)$ and heart $(F)$ of Tg, intense signal is mainly detected in vascular endothelial cells of medium to microsized vessels. $A-D, \times 400 ; E$ and $F$, $\times 200$.

nificant increase in NOS activity in the cytosol fraction and conversion to citrulline was significantly decreased on incubation without calcium and calmodulin or with L-NAME (data not shown).

Immunohistochemistry. Immunohistochemical staining for bovine eNOS in transgenic mice (line 22) showed that the in- creased immunoreactive product for bovine eNOS was predominantly localized in the endothelial cell lining of thoracic aorta from transgenic mice (Fig. $3 A$ ). Endogenous mouse eNOS in endothelial cells of the aorta from control littermates also cross-reacted with polyclonal anti-eNOS Ab, the same Ab as used for immunoblotting. However, the intensity of eNOS 
A

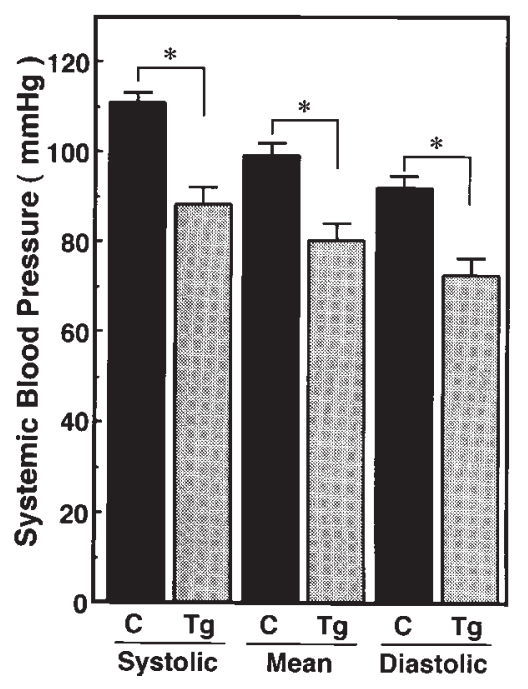

B

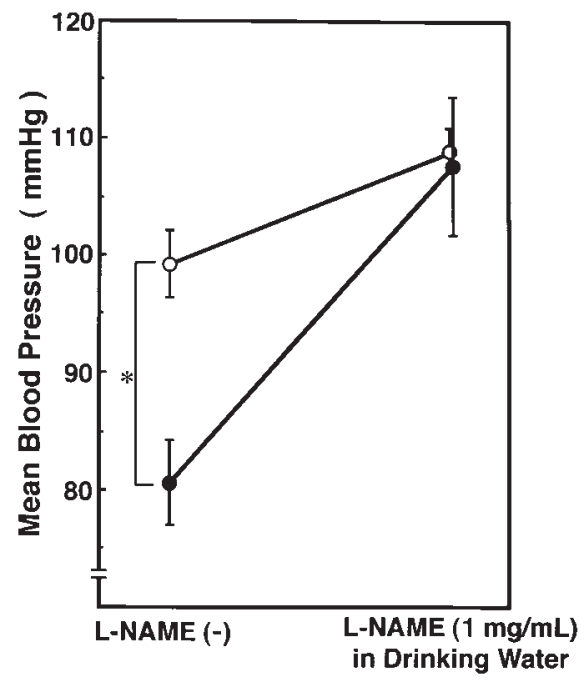

Figure 4. Systemic blood pressure analysis for conscious freely moving mice using a femoral arterial catheter. $(A)$ A summary of systolic, diastolic, and mean blood pressures $(\mathrm{mmHg})$ in control littermates $(C$, $n=9)$ and heterozygous eNOS transgenic mice ( $T g$, line 22, $n=10)$ is shown. $(B)$ Effects of chronic NOS inhibition by administration of L-NAME $(1 \mathrm{mg} / \mathrm{ml})$ in drinking water for $2 \mathrm{wk}$ on mean blood pressure. Four animals each are used for $\mathrm{C}$ and $\mathrm{Tg}$. Note that a significant reduction in blood pressure is observed in $\mathrm{Tg}$, but is completely reversed by chronic L-NAME treatment. Values are expressed as means \pm SEM. $* P<0.01, \mathrm{C}$ vs. Tg. immunoreactivity of transgenic endothelial cells was obviously stronger than that of control endothelial cells (Fig. 3, $A$ and $C$ ). Sections of transgenic mice and control littermates stained with nonimmune serum were entirely negative for staining (Fig. 3, $B$ and $D$ ). In the lung, a marked increase in eNOS expression was also observed in the endothelial cell lining of large pulmonary arteries and veins, and weak nonvascular expression was detected in the airway epithelium (Fig. $3 E$ ). As depicted in Fig. $3 F$, eNOS immunoreactivity was detected in medium-sized to small coronary arteries, rather than cardiac myocytes in the heart. These findings represent the predominant vascular targeting capacity of the preproET-1 promoter system (11).

Blood pressure and heart rate measurement. There is a gender difference in NO level which is possibly affected by estrogen (21). Therefore, we used male mice to assess the physiological consequences of eNOS overexpression. As shown in Fig. $4 A$, systemic arterial pressure was significantly lower in transgenic mice than in control littermates (systolic, $89 \pm 4$ $\mathrm{mmHg}$ in transgenic mice vs. $111 \pm 3 \mathrm{mmHg}$ in control littermates, $P<0.01$; diastolic, $73 \pm 3$ vs. $92 \pm 3$; $P<0.01$; mean, $81 \pm 4$ vs. $99 \pm 3, P<0.01)$. L-NAME administration for $2 \mathrm{wk}$ elevated the mean blood pressure in transgenic mice to a level comparable to that in L-NAME-treated control littermates (Fig. $4 \mathrm{~B}$ ) and the blood pressure was lower in independent transgenic lines (lines 65, 88, and 105) (data not shown). Accordingly, eNOS overexpression was responsible for the hypotension observed. Plasma nitrite and nitrate levels in transgenic mice were significantly higher than those in control mice (Table I). There was no significant change in heart rate as compared with control littermates. There was neither difference in body weight, organ weights, nor detectable macroscopic and microscopic abnormalities in transgenic mice killed at 2-3 mo of age. Blood urea nitrogen and plasma electrolyte concentrations were not significantly altered in transgenic mice. There were no significant differences in plasma renin activity and plasma catecholamine and ET-1 levels between control and transgenic mice (Table I).

Basal release of NO and cGMP levels. We next examined the effect of eNOS overexpression on basal tone of the aorta.
L-NA $(1-100 \mu \mathrm{M})$ dose-dependently contracted the aortic rings that had been moderately precontracted by $\mathrm{PGF}_{2 \alpha}$. Since L-NA-induced facilitation of $\mathrm{PGF}_{2 \alpha}$-induced contraction was not observed in the aortic rings treated with $100 \mu \mathrm{M}$ L-NAME before contraction by $\mathrm{PGF}_{2 \alpha}$ and was abolished by the addition of L-arginine (data not shown), the facilitated contraction was ascribed to endothelium-derived basal NO produced by

Table I. Basal Characteristics of Physiological Parameters and Biochemical Data

\begin{tabular}{lcc}
\hline & Control $(n)$ & Transgenic $(n)$ \\
\hline Body wt (g) & $26.2 \pm 1.1(13)$ & $26.0 \pm 0.7(13)$ \\
Heart wt $(\mathrm{mg})$ & $133.2 \pm 5.7(13)$ & $132.0 \pm 5.6(13)$ \\
Lung wt (mg) & $224.3 \pm 12.2(13)$ & $229.8 \pm 15.7(13)$ \\
Kidney wt (mg) & $194.6 \pm 8.2(13)$ & $191.2 \pm 8.5(13)$ \\
Mean blood pressure (mmHg) & $99 \pm 3(9)$ & $81 \pm 4(10)^{*}$ \\
Heart rate (bpm) & $534 \pm 26(9)$ & $588 \pm 19(10)$ \\
Plasma nitrite + nitrate $(\mu \mathrm{M})$ & $19.4 \pm 3.3(16)$ & $31.6 \pm 3.1(18)^{\ddagger}$ \\
Blood urea nitrogen $(\mathrm{mg} / \mathrm{ml})$ & $23.8 \pm 1.8(7)$ & $24.8 \pm 1.0(6)$ \\
Plasma sodium (meq/liter) & $148.3 \pm 1.4(7)$ & $148.2 \pm 1.0(6)$ \\
$\quad$ potassium $(\mathrm{meq} / \mathrm{liter})$ & $5.4 \pm 0.7(7)$ & $5.7 \pm 0.7(6)$ \\
$\quad$ chloride $(\mathrm{meq} / \mathrm{liter})$ & $113.0 \pm 1.4(7)$ & $113.5 \pm 1.6(6)$ \\
Urine volume $(\mathrm{ml} / 100 \mathrm{~g} / \mathrm{d})$ & $4.27 \pm 1.55(4)$ & $4.27 \pm 1.42(4)$ \\
Plasma renin activity $(\mathrm{ng} / \mathrm{ml} / \mathrm{h})$ & $33.0 \pm 10.0(11)$ & $28.6 \pm 9.6(8)$ \\
Plasma epinephrine $(\mathrm{pg} / \mathrm{ml})$ & $5223 \pm 436(5)$ & $4708 \pm 513(5)$ \\
$\quad$ norepinephrine $(\mathrm{pg} / \mathrm{ml})$ & $4937 \pm 480(5)$ & $3874 \pm 423(5)$ \\
Plasma ET-1 $(\mathrm{pg} / \mathrm{ml})$ & $1.46 \pm 0.14(11)$ & $1.84 \pm 0.18(9)$
\end{tabular}

Body weight and wet weights of organs were measured at $12-16 \mathrm{wk}$ of age. Urine volume was measured in three mice in a metabolic cage after a 6-h period without chow and expressed as milliliters per 100 grams of body weight per day. Blood pressure and heart rate were measured by direct arterial catheterization. In blood biochemical analysis, except for the measurement of plasma nitrite + nitrate in each mouse, pooled plasma obtained from two to three mice in each control or transgenic group was measured as one sample. All assays were performed as described in Methods. The number of samples are shown as $(n)$. Values are expressed as means \pm SEM. ${ }^{*} P<0.01,{ }^{\ddagger} P<0.05$, versus control. 
A

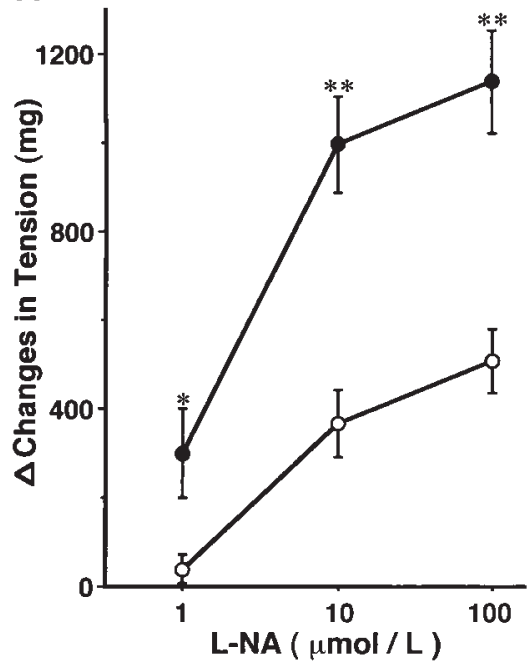

B

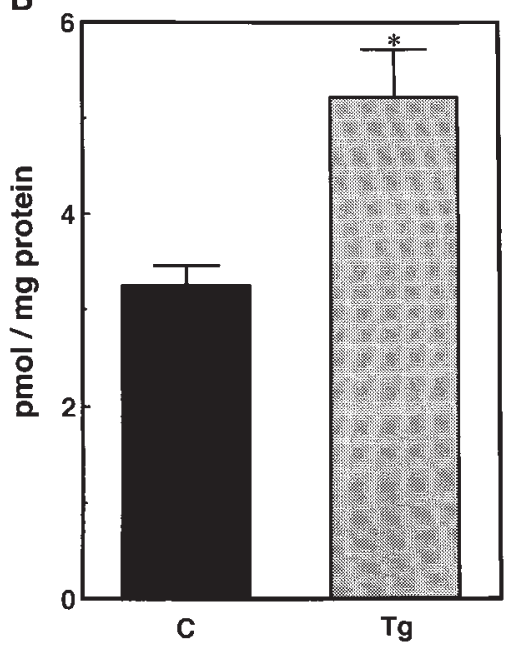

Figure 5. (A) Basal release of endothelium-derived NO indirectly estimated by L-NA-induced facilitation of $\mathrm{PGF}_{2 \alpha}{ }^{-}$ induced contraction. Moderate vascular tone was induced by $500 \mathrm{nM} \mathrm{PGF}_{2 \alpha}$ before cumulative additions of L-NA $(1-100 \mu \mathrm{M})$. L-NA-induced facilitation of the contraction was measured as milligram changes in developed tension. The magnitude is significantly greater in aortic rings isolated from eNOS-overexpressing mice ( $\mathrm{Tg}$, filled circles, $n=8$ ) than in those from control littermates (C, open circles, $n=6)$. Values are shown as means \pm SEM. $* P<0.05$, $* * P<0.01, \mathrm{C}$ vs. Tg. (B) Basal cGMP levels in the aorta determined by EIA. Tissue cGMP was extracted and subsequently acetylated for EIA. cGMP levels were calculated from the mean $\mathrm{OD}_{450}$ of triplicate wells in three independent experiments and expressed as picomoles per milligram of protein. The closed bar indicates control littermate $(C)$ value and the shaded bar transgenic mouse $(T g)$ value. Values are means \pm SEM of three independent determinations. $* P<0.05, \mathrm{C}$ vs. Tg.
eNOS. Fig. $5 \mathrm{~A}$ demonstrates that the extent of L-NA-induced endothelium-dependent facilitation of the contraction in transgenic mice was twice that in control littermates $(1,136 \pm 114$ vs. 506 $\pm 71 \mathrm{mg}$, at $100 \mathrm{mM}$ L-NA, respectively). Basal cGMP levels were obviously higher in the aortas from transgenic mice than in those from control littermates $(5.21 \pm 0.71$ vs. $3.26 \pm 0.20$ $\mathrm{pmol} / \mathrm{mg}$, respectively, Fig. $5 B$ ). Thus, the basal NO release estimated in isometric tension recordings was accompanied by increased basal cGMP levels.

Vascular reactivity to $\mathrm{NO}$ - and cAMP-mediated vasodilators and responses of $c G M P$ elevation. An endothelium-dependent vasodilator, ACh, produced concentration-dependent relaxation of aortas from both control and transgenic mice. This re- laxation was markedly attenuated by L-NAME treatment (100 $\mu \mathrm{M})$ (data not shown), suggesting that the relaxation to $\mathrm{ACh}$ is almost exclusively mediated by endothelium-derived NO. Unexpectedly, in eNOS-overexpressing mice, relaxation of the aorta in response to ACh was significantly reduced with an increase in $\mathrm{ED}_{50}$ and a decrease in the maximum response as compared with control littermates (Fig. $6 A$ and Table II). Similarly, relaxation to ATP $\gamma \mathrm{S}$, another endothelium-dependent vasodilator, was reduced in these mice (Table II). Relaxation to a NO donor, SNP, was reduced with a significant increase in $\mathrm{ED}_{50}$ in the transgenic mice (Fig. $6 \mathrm{~B}$ and Table II) and relaxation to NTG was also reduced (Table II), whereas cAMP-elevating or mobilizing agents, such as forskolin and dibutyryl
A

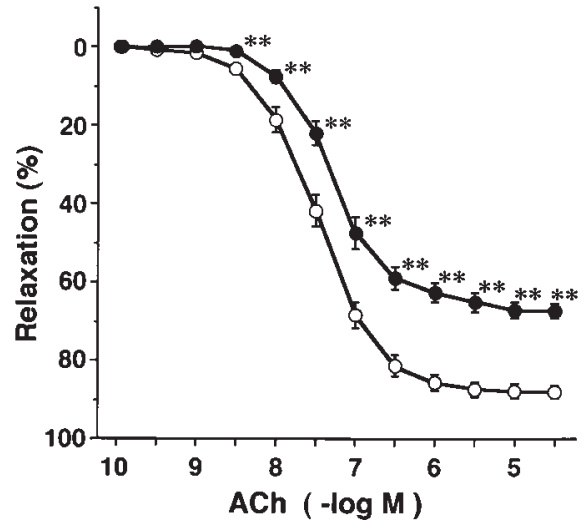

B

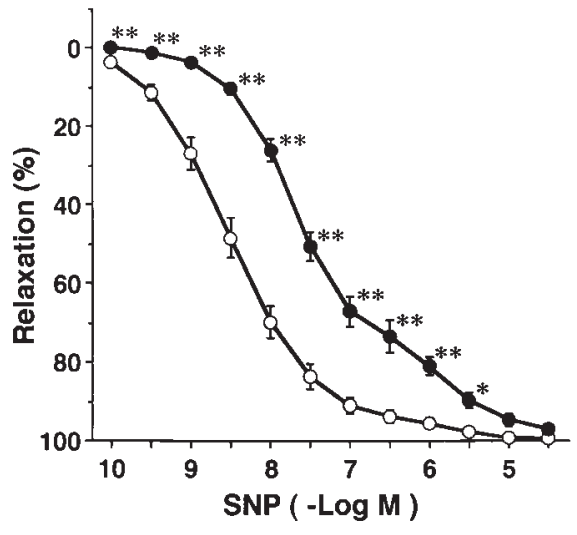

Figure 6. Relaxations in response to ACh and SNP of control and transgenic aortas. Vascular reactivity was determined as changes in isometric tension of aortic rings submaximally precontracted with $\mathrm{PGF}_{2 \alpha}$. Endothelium-dependent relaxations of the aortas from control ( $\mathrm{C}$, open circles) and eNOS transgenic mice ( $\mathrm{Tg}$, filled circles) by cumulative additions of $\mathrm{ACh}(100 \mathrm{pM}$ to 30 $\mu \mathrm{M}, A)$ and endothelium-independent relaxation by SNP ( $100 \mathrm{pM}$ to $30 \mu \mathrm{M}, B)$ were demonstrated. Concentrations of agents in the organ bath are expressed as negative $\log$ arithms $(-\log \mathrm{M})$. Values are means \pm SEM of 10 and 7 independent experiments ( $A$ and $B$, respectively). Note that markedly reduced response to both endothelium-dependent and -independent vasodilators was observed in the aortas from $\mathrm{Tg}$ compared with those from $\mathrm{C}$. $* P<0.05,{ }^{*} * P<0.01, \mathrm{C}$ vs. Tg by ANOVA with Bonferroni test. 
Table II. ED $D_{50}$ Values and Maximal Relaxations of the Aorta from Control and eNOS-overexpressing Mice

\begin{tabular}{|c|c|c|c|c|c|c|}
\hline \multirow[b]{2}{*}{ Agents } & \multicolumn{3}{|c|}{ Control mice } & \multicolumn{3}{|c|}{ eNOS-overexpressing mice } \\
\hline & $\mathrm{ED}_{50}$ & Max. Rel. & (n) & $\mathrm{ED}_{50}$ & Max. Rel. & (n) \\
\hline & $n M$ & $\%$ & & $n M$ & $\%$ & \\
\hline $\mathrm{ACh}$ & $32.7 \pm 3.2$ & $88.2 \pm 2.1$ & (10) & $62.9 \pm 11.3^{*}$ & $67.5 \pm 2.0^{\ddagger}$ & (12) \\
\hline $\mathrm{ATP} \gamma \mathrm{S}$ & $554.1 \pm 13.3$ & $96.7 \pm 0.8$ & (6) & $780.0 \pm 76.6^{*}$ & $83.6 \pm 2.2^{\ddagger}$ & (7) \\
\hline SNP & $3.9 \pm 0.9$ & $99.3 \pm 0.5$ & (8) & $44.0 \pm 4.7^{\ddagger}$ & $97.3 \pm 1.2$ & (8) \\
\hline NTG & $21.0 \pm 4.1$ & $89.3 \pm 2.5$ & (5) & $109.8 \pm 33.9 *$ & $62.0 \pm 3.4 *$ & (5) \\
\hline \multicolumn{7}{|c|}{ L-NAME-treated } \\
\hline SNP & $1.0 \pm 0.4$ & $100.0 \pm 0.0$ & (5) & $0.7 \pm 0.1$ & $100.0 \pm 0.0$ & (7) \\
\hline
\end{tabular}

For precise comparison of the sensitivity and maximal response of the aorta of control and transgenic mice, $\mathrm{ED}_{50}$ (concentration which produces $50 \%$ of the maximal relaxation to each agent) and maximal relaxation (percent PGF $_{2 \alpha}$-induced precontraction) were calculated from dose-response curves obtained. L-NAME-treated indicates measurements of isometric tension of aortas from chronic (2-3 wk) L-NAME-treated mice in the presence of L-NAME $(100 \mu \mathrm{M})$. Each value is a mean \pm SEM. The numbers of independent experiments are shown as $(n)$. Max. Rel., maximal relaxation. ${ }^{*} P<$ $0.05,{ }^{\ddagger} P<0.01$ vs. control mice.

cAMP, produced similar concentration-relaxation responses in the aortas from both control and transgenic mice (Fig. 7, $A$ and $B)$. In the aortas from transgenic mice treated with L-NAME for $3 \mathrm{wk}$, the hyporesponsiveness to SNP was completely recovered in the presence of L-NAME (Table II). Basal cGMP levels were increased, whereas the extents of cGMP elevation by ACh $(10 \mu \mathrm{M})$ and SNP (300 nM) were markedly decreased in transgenic aorta compared with those in control aorta (Table III).

\section{Discussion}

NO has been shown to be an endothelium-derived relaxing factor, and NO produced by eNOS diffuses from endothelial cells into underlying smooth muscle cells $(1,4)$. To study the physiological roles of $\mathrm{NO}$ as a local mediator, we generated eNOS transgenic mice with targeted expression to the vascular wall, particularly to endothelial cells in which endogenous
eNOS is constitutively expressed. Endothelium-specific in vivo transgene expression has been reported using promoters of endothelium-specific genes such as the murine Tie 2 gene, human vWf gene, and human intercellular adhesion molecule-2 (ICAM-2) gene (26-28). However, the Tie2 gene promoter was not active in adult mice and $\mathrm{vWf}$ gene promoter drove in vivo expression only to the blood vessels in the adult brain. ICAM-2 was also expressed weakly on monocytes, lymphocytes, platelets, and megakaryocytes, and use of human promoters would potently present species differences in the expression. In the murine preproET-1 promoter, the -1.4 to $-5.9-\mathrm{kb}$ promoter region is suggested to contain endothelial cell-specific elements and the larger fragments of the murine promoter are expected to exhibit stricter tissue-specific expression (12). We have succeeded in confining constitutive overexpression of functional eNOS to the vascular tissue in most organs using the 9.2-kb murine preproET-1 promoter.

A convincing in vivo feature observed in eNOS-overexpressing mice was hypotension. Since the hypotensive pheno-
A

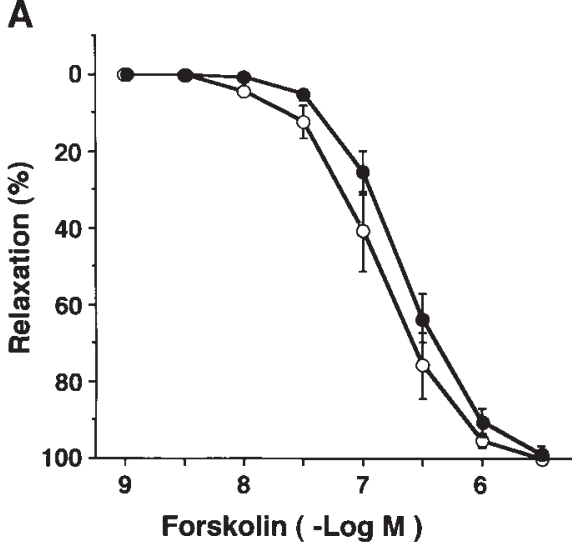

2068

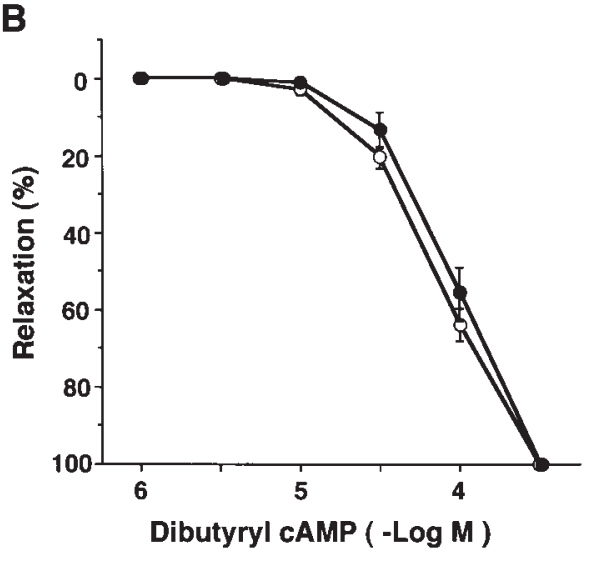

Figure 7. Relaxations in response to forskolin ( $1 \mathrm{nM}$ to $3 \mu \mathrm{M}, A$ ) and dibutyryl cAMP $(1 \mu \mathrm{M}$ to $300 \mu \mathrm{M}, B)$ of control (C, open circles) and transgenic aortas $(\mathrm{Tg}$, filled circles). An adenylate cyclase activator and a cAMP analogue were used to assess cAMP-mediated vasorelaxation. Concentrations of agents are expressed as $-\log$ M. Values are means \pm SEM of seven independent experiments (both $A$ and $B$ ). The dose-response curves for both agents were similar between $\mathrm{C}$ and $\mathrm{Tg}$, indicating that the cAMP-mediated pathway for vascular relaxation is intact in eNOS-overexpressing mice. Values of $\mathrm{ED}_{50}(\mathrm{nM})$ and maximal relaxation (\%) for forskolin were $156.0 \pm 45.6$ and $99.2 \pm 0.8$ in $\mathrm{C}$, and $221.7 \pm$ 38.9 and $98.5 \pm 1.5$ in $\mathrm{Tg}$, respectively (not significant). $\mathrm{ED}_{50}(\mu \mathrm{M})$ and maximal relaxation for dibutyryl cAMP were $70.8 \pm 6.5$ and $100.0 \pm 0.0$ in C, and 89.0 \pm 10.3 and $100.0 \pm$ 0.0 in $\mathrm{Tg}$, respectively (not significant). 
Table III. Increase in cGMP Levels in Response to Endothelium-dependent and -independent Vasodilators

\begin{tabular}{lccccc}
\hline & \multicolumn{2}{c}{ Control mice } & & \multicolumn{2}{c}{ eNOS-overexpressing mice } \\
\cline { 2 - 2 } & cGMP & $(n)$ & & cGMP & $(n)$ \\
\hline & pmol/mg & & $p m o l / m g$ & \\
No stimulation & $0.94 \pm 0.19$ & $(6)$ & & $1.19 \pm 0.41$ & $(6)$ \\
ACh $(10 \mu \mathrm{M})$ & $3.74 \pm 1.02$ & $(6)$ & & $2.64 \pm 0.74$ & $(6)$ \\
SNP $(300 \mathrm{nM})$ & $12.25 \pm 2.09$ & $(6)$ & & $5.95 \pm 1.66^{*}$ & $(6)$ \\
& & & & &
\end{tabular}

Response of cGMP elevations was evaluated as absolute cGMP levels determined by EIA in aortas ex vivo stimulated by agents at indicated concentrations for 1 min. cGMP was extracted and two doses of the aliquots were each assayed in duplicate, according to the manufacturer's protocol. ACh and SNP were representatively used to measure endothelium-dependent and -independent cGMP elevations, respectively. No stimulation means stimulation with vehicle (Krebs' solution) after the preincubation with the same solution for $60 \mathrm{~min}$. Values were obtained from individual aortas from $(n)$ animals and are expressed as means \pm SEM. $* P<0.05$ vs. control mice.

type was also observed in independent transgenic lineages, the functional effects of eNOS overexpression in line 22 were not due to spurious positional effects of transgene insertion. Hypertension in mice lacking eNOS has been reported by two groups $(6,7)$ and our model provides another in vivo validation for that NO produced by eNOS itself regulates blood pressure. The mechanisms of hypotension due to eNOS overexpression have not been determined fully. However, eNOS encoded by the transgene must have contributed to the reduction in blood pressure because chronic administration of L-NAME completely reversed hypotension in transgenic mice without paradoxical reduction in blood pressure observed in L-NA-treated eNOS knockout mice (6). Both cardiac output and peripheral arterial resistance determine blood pressure and depression of cardiac function by NO may lead to decreased cardiac output. However, in the present model, bovine eNOS was not identified in cardiac myocytes. Of note was that the hypotension in the transgenic mice was associated with both a decrease in basal tone of the aorta and an increase in its basal cGMP levels. Because of technical difficulties, we could not determine total vascular resistance and the vascular tone examined in the aorta might not always reflect that in the resistance vessels which regulate blood pressure. But, indeed, the transgene was obviously expressed in large or medium- to micro-sized vessels in the heart and lung (Fig. 3, $E$ and $F$ ). Therefore, it is likely that enhanced $\mathrm{NO}$ release exerted vasorelaxant effects in types of vessels other than the aorta and increases in basal NO release reduced basal vascular tone in resistance vessels, thereby produced hypotension. Hypotension has also been observed in transgenic mouse models with overexpression of natriuretic peptides, kallikrein, and bradykinin receptor (29-32). Our model exhibited hypotension without increases in heart rate or urine volume, similar to mice overexpressing natriuretic peptides that yielded no changes in indicators of a volume-depleted state $(29,30)$. These studies imply that enhanced vasodilatory action of cGMP-mediated pathway by either NO or natriuretic peptides in the vascular wall sufficiently reduces blood pressure.

Blood pressure is regulated by integrative neurohumoral factors. Compensatory mechanisms may operate for the reduction in blood pressure due to chronic activation of the NO pathway. Recent reports have demonstrated that NO interacts with the renin-angiotensin system and also the cyclooxygenase-prostaglandin system. Elevated plasma renin concentration was observed in eNOS-deficient mice (7). However, there were no significant alterations in plasma renin activity, plasma catecholamine, or ET-1 levels in our transgenic mice (Table I) and the responsiveness of mouse aorta was not modified after preincubation with indomethacin in isometric tension recordings (data not shown). Collectively, these findings further support the notion that the direct vasodilatory action of overproduced NO is mainly responsible for hypotension without potential influence of major neurohumoral systems regulating blood pressure.

The most surprising finding observed in eNOS-overexpressing mice was the reduced vasorelaxant response to NOmediated vasodilators (Fig. 6). Recent reports of adenovirusmediated eNOS gene transfer into the endothelium or the adventitia have demonstrated the enhanced endotheliumdependent relaxations in response to $\mathrm{ACh}$ and calcium ionophore $(10,33,34)$. We for the first time demonstrated that chronic eNOS overexpression results in attenuation rather than enhancement of NO-mediated vasorelaxation. The difference in vascular reactivity observed between animals with gene transfer and our transgenic model may be possibly due to animal species used, the expression site of eNOS, relative intensity of gene expression achieved depending on the promoter used in each model, or the duration of gene expression. We could not define the exact mechanisms, but believe that the long duration of eNOS overexpression in the transgenic mice is probably involved. It is likely that, in contrast to the acute effect of eNOS gene transfer, the chronic increase in basal NO release due to eNOS overexpression elicits the reversible hyporesponsiveness in NO-cGMP pathway. It has been established pharmacologically that chronic in vivo treatment of rabbits and rats with organic nitrate results in development of nitrate tolerance and cross-tolerance to other nitrovasodilators and endothelium-dependent vasodilators $(35,36)$. Inversely, the sensitivity of isolated rat aorta to NO donors was increased after removal of the endothelium or treatment with a NOS inhibitor (37). Recently, relaxation of the carotid artery in response to low concentrations of SNP was shown to be enhanced in eNOS-deficient mice (38). Our findings are consistent with these reports, which imply that alterations in basal NO release modulate vascular reactivity to NO.

In eNOS-overexpressing mice, cAMP-mediated vasorelaxation was not altered (Fig. 7), whereas increases in cGMP levels in response to ACh and SNP were depressed in spite of the increased basal cGMP levels (Fig. $5 B$ and Table III). Concentration-dependent increases in cGMP by SNP were significantly attenuated after chronic NTG injection and were potentiated by endothelial denudation or NOS inhibition of the aorta $(35,37)$. Soluble guanylate cyclase (sGC) purified from NO donor-pretreated rat aorta exhibited desensitization to NO donors (39). sGC mRNA and protein levels and its activity were decreased in cultured smooth muscle cells exposed to NO donors, a cGMP analogue, or an inhibitor of cGMP phosphodiesterase $(40,41)$. In view of these reports, desensitization of sGC by continuous overactivation is, at least in part, implicated in the reduced vascular reactivity in eNOS-overexpressing mice. Furthermore, impairments of signaling pathway after 
cGMP elevation may occur. Whether it is also the case with our mouse model remains to be clarified.

In conclusion, we generated transgenic mice overexpressing eNOS in the vascular wall to study the local effects of NO. eNOS-overexpressing mice displayed marked hypotension which was associated with reduced basal vascular tone and reduced vascular reactivity to NO. Our mouse model provided new insights into the in vivo mechanisms of nitrate tolerance in addition to the essential role of eNOS in physiological blood pressure regulation and could be a novel useful tool to explore the pathophysiological roles of NO in the cardiovascular system.

\section{Acknowledgments}

The authors thank Prof. David G. Harrison (Cardiovascular Division, Emory University School of Medicine) and Dr. Jennifer S. Pollock (Abbott Laboratories, Abbott Park, IL) for bovine aortic eNOS cDNA and an mAb against bovine eNOS (H32). We wish to thank Drs. Akio Inui and Minoru Okita (The Second Department of Internal Medicine, Kobe University School of Medicine) for the technical advice to generate transgenic mice and Dr. Katsuo Kamata (Hoshi University, Tokyo) for his advice and help on isometric tension recordings of the mouse aorta. We gratefully appreciate Seiko Tsutsui and Kiyoko Matsui for their support with animal care and secretarial assistance.

This work was supported by grants-in-aid for Scientific Research (No. 08457209) from Ministry of Education, Science and Culture, Japan (1995-97) and grants-in-aid for the research on cardiovascular disease from the Ministry of Health and Welfare, Japan (1995-97), a grant from Japan Cardiovascular Research Foundation, a grant from Research for Molecular Cardiology, and a grant from Kanae Foundation of Research for New Medicine.

\section{References}

1. Moncada, S., R.M. Palmer, and E.A. Higgs. 1991. Nitric oxide: physiology, pathophysiology, and pharmacology. Pharmacol. Rev. 43:109-142.

2. Dinerman, J.L., C.J. Lowenstein, and S.H. Snyder. 1993. Molecular mechanisms of nitric oxide regulation. Potential relevance to cardiovascular disease. Circ. Res. 73:217-222.

3. Dzau, V.J., and G.H. Gibbons. 1991. Endothelium and growth factors in vascular remodeling of hypertension. Hypertension. 18(Suppl. III):III115III121.

4. Nathan, C., and Q.-W. Xie. 1994. Nitric oxide synthases: roles, tolls, and controls. Cell. 78:915-918.

5. Moncada, S., and E.A. Higgs. 1993. The L-arginine-nitric oxide pathway. N. Engl. J. Med. 329:2002-2012.

6. Huang, P.L., Z. Huang, H. Mashimo, K.D. Bloch, M.A. Moskowitz, J.A. Bevan, and M.C. Fishman. 1995. Hypertension in mice lacking the gene for endothelial nitric oxide synthase. Nature. 377:239-242.

7. Shesely, E.G., N. Maeda, H.S. Kim, K.M. Desai, J.H. Krege, V.E. Laubach, P.A. Sherman, W.C. Sessa, and O. Smithies. 1996. Elevated blood pressures in mice lacking endothelial nitric oxide synthase. Proc. Natl. Acad. Sci. USA. 93:13176-13181.

8. von der Leyen, H.E., G.H. Gibbons, R. Morishita, N.P. Lewis, L. Zhang, M. Nakajima, Y. Kaneda, J.P. Cooke, and V.J. Dzau. 1995. Gene therapy inhibiting neointimal vascular lesion: in vivo transfer of endothelial cell nitric oxide synthase gene. Proc. Natl. Acad. Sci. USA. 92:1137-1141.

9. Lin, K.-F., L. Chao, and J. Chao. 1997. Prolonged reduction of high blood pressure with human nitric oxide synthase gene delivery. Hypertension. 30:307313.

10. Ooboshi, H., Y. Chu, D. Rios, F.M. Faraci, B.L. Davidson, and D.D. Heistad. 1997. Altered vascular function after adenovirus-mediated overexpression of endothelial nitric oxide synthase. Am. J. Physiol. 273(Heart Circ. Physiol. 42):H265-H270.

11. Harats, D., H. Kurihara, P. Belloni, H. Oakley, A. Ziober, D. Ackley, G. Cain, Y. Kurihara, R. Lawn, and E. Sigal. 1995. Targeting gene expression to the vascular wall in transgenic mice using the murine preproendothelin-1 promoter. J. Clin. Invest. 95:1335-1344.

12. Nishida, K., D.G. Harrison, J.P. Navas, A.A. Fisher, S.P. Dockery, M. Uematsu, R.M. Nerem, R.W. Alexander, and T.J. Murphy. 1992. Molecular cloning and characterization of the constitutive bovine aortic endothelial cell nitric oxide synthase. J. Clin. Invest. 90:2092-2096.

13. Maemura, K., H. Kurihara, O. Ueda, Y. Kurihara, T. Kuwaki, H Morita, T. Kodama, H. Suzuki, M. Kumada, T. Ishikawa, and Y. Yazaki. 1996. Generation and analysis of transgenic mice overexpressing endothelin-1. Circulation. 94:I-531.

14. Hogan, B., R. Beddington, F. Costantini, and E. Lacy. 1994. Manipulating the Mouse Embryo: A Laboratory Manual. 2nd ed. Cold Spring Harbor Laboratory, Cold Spring Harbor, NY. 127-188.

15. Chomczynski, P., and N. Sacchi. 1987. Single-step method of RNA isolation by acid guanidinium thiocyanate-phenol-chloroform extraction. Anal. Biochem. 162:156-159.

16. Hirata, K., N. Miki, Y. Kuroda, T. Sakoda, S. Kawashima, and M. Yokoyama. 1995. Low concentration of oxidized low-density lipoprotein and lysophosphatidylcholine upregulate constitutive nitric oxide synthase mRNA expression in bovine aortic endothelial cells. Circ. Res. 76:958-962.

17. Bradford, M.M. 1976. A rapid and sensitive method for the quantitation of microgram quantities of protein utilizing the principle of protein-dye binding. Anal. Biochem. 72:248-254.

18. Pollock, J.S., M. Nakane, L.D. Buttery, A. Martinez, D. Springall, J.M. Polak, U. Forstermann, and F. Murad. 1993. Characterization and localization of endothelial nitric oxide synthase using specific monoclonal antibodies. Am. J. Physiol. 265(Cell. Physiol. 34):C1379-C1387.

19. Ohashi, Y., M. Katayama, K. Hirata, M. Suematsu, S. Kawashima, and M. Yokoyama. 1993. Activation of nitric oxide synthase from cultured aortic endothelial cells by phospholipids. Biochem. Biophys. Res. Commun. 195:1314 1320

20. Kanazawa, K., S. Kawashima, S. Mikami, Y. Miwa, K. Hirata, M. Suematsu, Y. Hayashi, H. Itoh, and M. Yokoyama. 1996. Endothelial constitutive nitric oxide synthase protein and mRNA increased in rabbit atherosclerotic aorta despite impaired endothelium-dependent vascular relaxation. Am. J. Pathol. 148:1949-1956.

21. Kamata, K., M. Sugiura, S. Kojima, and Y. Kasuya. 1996. Preservation of endothelium-dependent relaxation in cholesterol-fed and streptozotocininduced diabetic mice by the chronic administration of cholestyramine. $\mathrm{Br}$. $J$. Pharmacol. 118:385-391.

22. Hayashi, T., J.M. Fukuto, L.J. Ignarro, and G. Chaudhuri. 1992. Basa release of nitric oxide from aortic rings is greater in female rabbits than in male rabbits: implications for atherosclerosis. Proc. Natl. Acad. Sci. USA. 89:1125911263.

23. Rubanyi, G.M., A.D. Freay, K. Kauser, D. Sukovich, G. Burton, D.B Lubahn, J.F. Couse, S.W. Curtis, and K.S. Korach. 1997. Vascular estrogen receptors and endothelium-derived nitric oxide production in the mouse aorta. Gender difference and effect of estrogen receptor gene disruption. J. Clin. Invest. 99:2429-2437.

24. Janssens, S.P., K.D. Bloch, Z. Nong, R.D. Gerard, P. Zoldhelyi, and D. Collen. 1996. Adenoviral-mediated transfer of the human endothelial nitric oxide synthase gene reduces acute hypoxic pulmonary vasoconstriction in rats. $J$. Clin. Invest. 98:317-324

25. Moshage, H., B. Kok, J.R. Huizenga, and P.L.M. Jansen. 1995. Nitrite and nitrate determinations in plasma: a critical evaluation. Clin. Chem. 41:892896.

26. Schlaeger, T.M., Y. Oin, Y. Fujiwara, J. Magram, and T.N. Sato. 1995. Vascular endothelial cell lineage-specific promoter in transgenic mice. Development. 121:1089-1098.

27. Aird, W.C., N. Jahroudi, G.H. Weiler, H.B. Rayburn, and R.D. Rosenberg. 1995. Human von Willebrand factor gene sequences target expression to a subpopulation of endothelial cells in transgenic mice. Proc. Natl. Acad. Sci. USA. 92:4567-4571.

28. Cowan, P.J., T.A. Shinkel, E.J. Witort, H. Barlow, M.J. Pearse, and A.J. d'Apice. 1996. Targeting gene expression to endothelial cells in transgenic mice using the human intercellular adhesion molecule 2 promoter. Transplantation. 62:155-160.

29. Steinhelper, M.E., K.L. Cochrane, and L.J. Field. 1990. Hypotension in transgenic mice expressing atrial natriuretic factor fusion genes. Hypertension. 16:301-307.

30. Ogawa, Y., H. Itoh, N. Tamura, S. Suga, T. Yoshimasa, M. Uehira, S. Matsuda, S. Shiono, H. Nishimoto, and K. Nakao. 1994. Molecular cloning of the complementary DNA and gene that encode mouse brain natriuretic peptide and generation of transgenic mice that overexpress the brain natriuretic peptide gene. J. Clin. Invest. 93:1911-1921.

31. Wang, J., W. Xiong, Z. Yang, T. Davis, M.J. Dewey, J. Chao, and L. Chao. 1994. Human tissue kallikrein induces hypotension in transgenic mice. Hypertension. 23:236-243.

32. Wang, D.-Z., L. Chao, and J. Chao. 1997. Hypotension in transgenic mice overexpressing human bradykinin B2 receptor. Hypertension. 29:488-493.

33. Kullo, I.J., G. Mozes, R.S. Schwartz, P. Gloviczki, M. Tsutsui, Z.S. Katusic, and T. O'Brien. 1997. Enhanced endothelium-dependent relaxations after gene transfer of recombinant endothelial nitric oxide synthase to rabbit carotid arteries. Hypertension. 30:314-320.

34. Kullo, I.J., G. Mozes, R.S. Schwartz, P. Gloviczki, T.B. Crotty, D.A Barber, Z.S. Katusic, and T. O'Brien. 1997. Adventitial gene transfer of recombinant endothelial nitric oxide synthase to rabbit carotid arteries alters vascular 
reactivity. Circulation. 96:2254-2261.

35. Molina, C.R., J.W. Andresen, R.M. Rapoport, S. Waldman, and F. Murad. 1987. Effect of in vivo nitroglycerin therapy on endothelium-dependent and independent vascular relaxation and cyclic GMP accumulation in rat aorta. J. Cardiovasc. Pharmacol. 10:371-378.

36. Münzel, T., H. Seyegh, B.A. Freeman, M.M. Tarpey, and D.G. Harrison. 1995. Evidence for enhanced vascular superoxide anion production in nitrate tolerance. A novel mechanism underlying tolerance and cross-tolerance. J. Clin. Invest. 95:187-194.

37. Moncada, S., D.D. Rees, R. Schulz, and R.M.J. Palmer. 1991. Development and mechanism of a specific supersensitivity to nitrovasodilators after inhibition of vascular nitric oxide synthesis in vivo. Proc. Natl. Acad. Sci. USA. 88: 2166-2170.
38. Faraci, F.M., C.D. Sigmund, E.G. Shesely, N. Maeda, and D.D. Heistad. 1998. Responses of carotid artery in mice deficient in expression of the gene for endothelial NO synthase. Am. J. Physiol. 274(Heart Circ. Physiol. 43):H564H570.

39. Waldman, S.A., R.M. Rapoport, R. Ginsburg, and F. Murad. 1986. Desensitization to nitroglycerin in vascular smooth muscle from rat and human. Biochem. Pharmacol. 35:3525-3531.

40. Filippov, G., D.B. Bloch, and K.D. Bloch. 1997. Nitric oxide decreases stability of mRNAs encoding soluble guanylate cyclase subunits in rat pulmonary artery smooth muscle cells. J. Clin. Invest. 100:942-948.

41. Papapetropoulos, A., C.Y. Go, F. Murad, and J.D. Catravas. 1996. Mechanisms of tolerance to sodium nitroprusside in rat cultured aortic smooth muscle cells. Br. J. Pharmacol. 117:147-155. 